\title{
Pulmonary Hypertension in a Large Cohort with Hereditary Hemorrhagic Telangiectasia
}

\author{
Veronique Vorselaars ${ }^{a}$ Sebastiaan Velthuis ${ }^{a}$ Marco van Gent ${ }^{a}$ \\ Cornelis Westermann ${ }^{b}$ Repke Snijder ${ }^{b}$ Johannes Mager ${ }^{b}$ Martijn Post $^{a}$ \\ Departments of a Cardiology and ${ }^{b}$ Pulmonology, St. Antonius Hospital Nieuwegein, Nieuwegein, The Netherlands
}

\section{Keywords}

Pulmonary hypertension · Heritable pulmonary arterial hypertension · Hereditary hemorrhagic telangiectasia .

Echocardiography

\begin{abstract}
Background: Hereditary hemorrhagic telangiectasia (HHT) is a vascular disorder characterized by arteriovenous malformations in the brain, liver, and lungs. Pulmonary hypertension $(\mathrm{PH})$ is increasingly recognized as a severe complication of HHT. However, there are no studies describing the prevalence of PH in HHT compared to HHT-negative controls. Objective: To assess the estimated prevalence of $\mathrm{PH}$ in patients with HHT compared to HHT-negative controls. Methods: All consecutive subjects screened for HHT with available genetic testing and echocardiography-based peak tricuspid regurgitation velocity (TRV) measurement were included. Increased-probability PH was defined as a TRV $>2.8 \mathrm{~m} / \mathrm{s}$. $\boldsymbol{R e}$ sults: In 578 subjects, both echocardiography and genetic testing were available. A reliable TRV was measured in 383 (66.3\%), of whom 127 had HHT type 1 (HHT1), 150 had HHT type 2 (HHT2), and 106 were HHT-negative controls, with a mean TRV of $2.3 \pm 0.4,2.4 \pm 0.5$, and $2.2 \pm 0.3 \mathrm{~m} / \mathrm{s}$, respectively ( $p=0.008$ and $p<0.001$ vs. controls). Increased-prob-
\end{abstract}

\section{KARGER}

(C) 2017 S. Karger AG, Basel

E-Mail karger@karger.com

www.karger.com/res ability $\mathrm{PH}$ was found in 42 subjects (8.7\% in $\mathrm{HHT} 1,18.0 \%$ in $\mathrm{HHT} 2$, and $3.8 \%$ in HHT-negative controls). HHT2 and hepatic arteriovenous malformations (HAVMs) were the most important predictors for increased-probability $\mathrm{PH}$ (odds ratio 5.6, $p=0.002$, and odds ratio 11.3, $p<0.001$, respectively). Heritable pulmonary arterial hypertension (HPAH) was diagnosed in 2 patients $(0.7 \%)$ and only found in $\mathrm{HHT} 2(1.3 \%)$. Conclusion: The estimated prevalence of $\mathrm{PH}$ is higher in $\mathrm{HHT}$ patients compared to HHT-negative controls. This increase is especially present in HHT2 and mainly associated with the presence of HAVMs. HPAH appears to be rare in HHT patients and was only diagnosed in HHT2.

(c) 2017 S. Karger AG, Basel

\section{Introduction}

Hereditary hemorrhagic telangiectasia (HHT) is an autosomal dominant inherited disorder characterized by abnormal artery-to-vein communications, ranging from small telangiectasia in skin and mucosal membranes to large arteriovenous malformations (AVMs), predominantly in the brain, liver, and lungs [1-4].

HHT consists of two main subtypes, HHT type 1 (HHT1) and type 2 (HHT2), both resulting from differ-

Veronique M.M. Vorselaars, MD

Department of Cardiology, St. Antonius Hospital Koekoekslaan 1

NL-3435 CM Nieuwegein (The Netherlands)

E-Mail v.vorselaars@ antoniusziekenhuis.nl 
ent gene mutations in two genes encoding for TGF $\beta$ receptors $[2,5,6]$. HHT1 results from mutations in the ENG gene on chromosome 9 encoding the protein endoglin [6], whereas HHT2 results from mutations in the activin receptor-like kinase 1 (ACVRL1) gene on chromosome 12 encoding the protein ALK-1 [7].

Pulmonary hypertension $(\mathrm{PH})$ is increasingly recognized as a potential important complication of HHT, as it is associated with poor prognosis and might lead to progressive right-sided heart failure and premature death [8-10].

There are two potential mechanisms that could explain the presence of $\mathrm{PH}$ in patients with HHT. PH may result from a high pulmonary blood flow, which is due to the high cardiac output (CO) state associated with hepatic AVMs (HAVMs) [11-13]. Furthermore, HHT-related gene mutations in $A C V R L 1$ or ENG potentially predispose to the development of heritable pulmonary arterial hypertension (HPAH) with a normal or low $\mathrm{CO}$ [14-19].

Currently, transthoracic contrast echocardiography (TTCE) is recommended in all HHT patients for the detection of pulmonary AVMs, which could also be used for $\mathrm{PH}$ screening [2].

Previous studies describing the association between $\mathrm{PH}$ and HHT suffer from major limitations, including small sample size, inclusion of patients with known history of $\mathrm{PH}$ in whom symptoms of HHT were present, and not differentiating between HHT types [14-22]. In the current study, we report the estimated prevalence of allcause $\mathrm{PH}$ in a large well-defined cohort of patients with HHT compared to HHT-negative controls.

\section{Methods}

\section{Study Population}

All consecutive subjects older than 15 years who were screened for HHT between May 2004 and October 2012 at St. Antonius Hospital (designated by the international HHT foundation as an HHT center of excellence) were eligible for inclusion. The clinical diagnosis of HHT was established according to the Curaçao criteria [1]. Genetic testing for the HHT-causing mutation was offered to all screened subjects and performed as previously described [23]. Subjects were included for further analysis if definite mutation analysis was available and classified as HHT1, HHT2, and HHT-negative controls. Subjects were included in the control group when genetic testing for the known HHT-causing family mutation (i.e., the mutation present in a family member) was negative. Subjects who underwent HHT screening with negative genetic testing for $E N G$ and $A C V R L 1$ but no known family mutation were excluded from this study. This prevented patients with clinically diagnosed HHT in whom genetic testing could not detect a

Pulmonary Hypertension in Patients with HHT disease-causing mutation from being falsely classified as HHTnegative. Subjects without a reliable peak tricuspid regurgitation velocity (TRV) measurement on TTCE were excluded [24, 25].

Screening for the presence of pulmonary AVMs was routinely performed with TTCE and/or chest computed tomography as previously described $[26,27]$. Screening for HAVMs was only performed in case of suspected HAVMs by medical history, physical examination, or blood test results (abnormal gamma-glutamyl transpeptidase or alkaline phosphatase).

All subjects provided informed consent, and the study was approved by the institutional review board of St. Antonius Hospital (R\&D/Z13.040).

\section{Screening and Diagnosis of $\mathrm{PH}$}

A commercially available Philips IE33 ultrasound instrument and an S5-1 transducer (Philips Medical Systems, Best, The Netherlands) were used for cardiac imaging. Peak TRV was measured with continuous wave Doppler. Intermediate-probability $\mathrm{PH}$ was defined as a TRV $>2.8$ and $\leq 3.4 \mathrm{~m} / \mathrm{s}$ and high-probability $\mathrm{PH}$ as a TRV $>3.4 \mathrm{~m} / \mathrm{s}$, according to the international guidelines for the diagnosis and treatment of $\mathrm{PH}$ [9]. The term increased probability was used to describe both intermediate- and high-probability $\mathrm{PH}$. Atrial dimensions and area, right ventricular (RV) dimension, CO, and left ventricular ejection fraction were obtained from the apical four-chamber view. Two independent cardiologists blinded to other characteristics, with experience in both HHT and $\mathrm{PH}$, reviewed all TTCEs.

$\mathrm{PH}$ was defined as a mean pulmonary artery pressure (PAP) of $\geq 25 \mathrm{~mm} \mathrm{Hg}$ at rest obtained by right heart catheterization (RHC) [9]. During RHC, we measured systolic, diastolic, and mean PAP, right atrial (RA) pressure, pulmonary artery wedge pressure (PAWP), RV pressure, pulmonary vascular resistance (PVR), CO, cardiac index, and saturation in different compartments. All patients classified as high-probability $\mathrm{PH}$ were discussed in a multidisciplinary meeting. Classification and indication for RHC was performed according to the international guidelines $[9,28]$.

\section{Statistical Analysis}

Descriptive statistics were used to describe patient characteristics. Continuous variables were reported as mean \pm standard deviation. Proportions were given by numbers and corresponding percentages. Differences between groups were analyzed by the independent Student $t$ test for continues variables and the $\chi^{2}$ test or the Fisher exact test for nominal variables. Univariate statistical analysis with logistic regression was used to identify predictors for increased-probability PH. Odds ratios (ORs) with their 95\% confidence intervals (CIs) were calculated, for continuous variables ORs were calculated per unit of measurement. Statistics were performed using a statistical software package (SPSS, version 22; SPSS Inc., Chicago, IL, USA).

\section{Results}

\section{Study Population}

Between May 2004 and October 2012, in a total of 658 subjects screened for HHT, mutation analysis was available (Fig. 1). Out of these 658 subjects an adequate TTCE

Respiration 2017;94:242-250 
was done in 578 (87.8\%). In 27 subjects no TTCE was done due to failure of placement of the intravenous line or patient refusal. In 53 subjects the TTCE quality was too poor for interpretation. A reliable TRV was measured in 383 subjects $(66.3 \%)$, of whom 127 had HHT1 $(61.4 \% \mathrm{fe}-$ male, mean age $44.2 \pm 15.6$ years), 150 had HHT2 (59.3\% female, mean age $48.9 \pm 14.2$ years), and 106 were HHTnegative controls $(62.3 \%$ female, mean age $38.6 \pm 12.8$ years). The mean TRV was higher in the HHT1 $(2.3 \pm$ $0.4 \mathrm{~m} / \mathrm{s}, p=0.008)$ and HHT2 $(2.4 \pm 0.5 \mathrm{~m} / \mathrm{s}, p<0.001)$ patients compared to the HHT-negative controls $(2.2 \pm$ $0.3 \mathrm{~m} / \mathrm{s}$ ). The characteristics of our study population are listed in Table 1.

\section{Increased-Probability $\mathrm{PH}$}

Increased-probability $\mathrm{PH}$ was found in 42 subjects (11.0\%), 11 (8.7\%) with HHT1, 27 (18.0\%) with HHT2, and $4(3.8 \%)$ HHT-negative controls (HHT versus HHTnegative $p=0.005$; Table 2). Within these groups, HAVMs were found in $9.1,44.4$, and $0 \%$, respectively. The mean $\mathrm{CO}$ was $3.9 \pm 1.0 \mathrm{~L} / \mathrm{min}, 5.1 \pm 1.6 \mathrm{~L} / \mathrm{min}$, and $4.4 \pm 0.9 \mathrm{~L} /$ min, respectively. In patients with HAVMs, the mean CO was $5.8 \mathrm{~L} / \mathrm{min}$ compared to $4.1 \mathrm{~L} / \mathrm{min}$ in those without HAVMs.

\section{Predictors of $\mathrm{PH}$}

Presence of $A C V R L 1$ mutation and HAVMs were the most important predictors for increased-probability $\mathrm{PH}$ in univariate analysis (OR 5.6, 95\% CI 1.9-16.5, $p=0.002$, and OR 11.3, 95\% CI 4.8-26.7, $p<0.001$, respectively). Other predictors were age, hemoglobin levels, left atrial (LA) area, and partial oxygen pressure (Table 3 ).

\section{High-Probability $\mathrm{PH}$}

In the HHT1 group, 2 patients (1.6\%) were classified as high-probability $\mathrm{PH}$. Both patients were older than 65 years and classified as $\mathrm{PH}$ due to left heart disease (World Health Organization [WHO] class II). Patient 1 had mitral valve regurgitation and diastolic dysfunction of the left ventricle. Patient 2 had both systolic and diastolic dysfunction of the left ventricle. Both had normal liver function and $\mathrm{CO}$.

In the HHT2 group, 6 patients (4.0\%) were classified as high-probability $\mathrm{PH}$, of whom 4 underwent $\mathrm{RHC}$ (patients $3,4,5,6)$. Patient 1 and 2 were classified as $\mathrm{PH}$ due to diastolic dysfunction of the left ventricle (WHO class II). Two patients ( $1.3 \%$, patients 3 and 4 ) were diagnosed with HPAH. Patient 3 had a mutation known for HPAH (ALK;7:DelG1042stop) and HAVMs (RHC: PAP 75/30/ $45 \mathrm{~mm} \mathrm{Hg}$, PAWP $15 \mathrm{~mm} \mathrm{Hg}$, PVR 3.4 Wood units

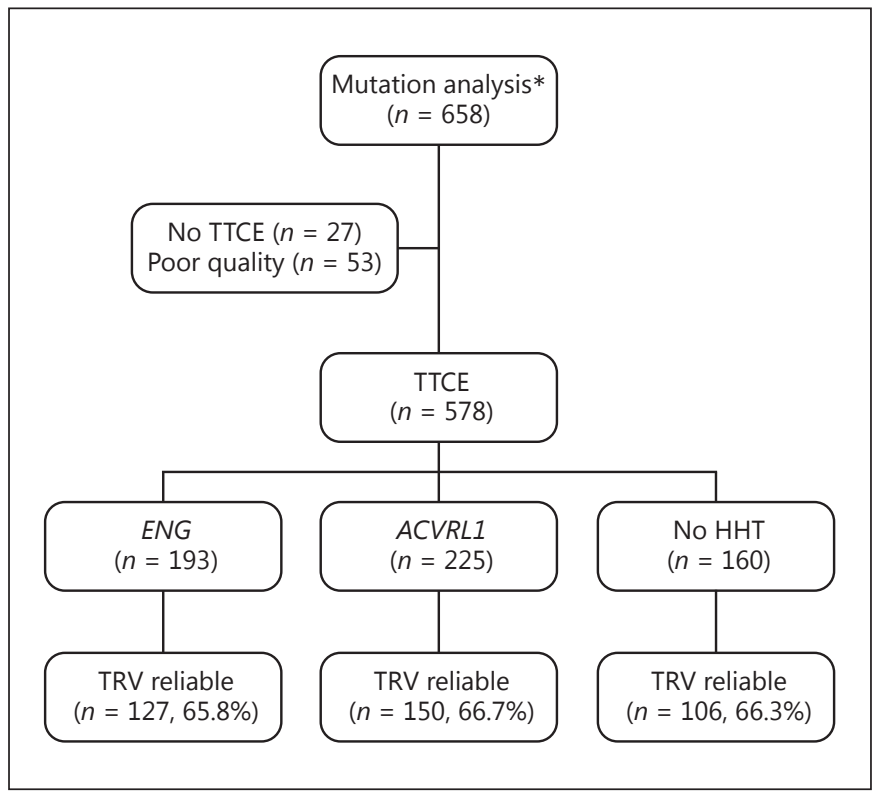

Fig. 1. Flowchart of patient selection. ACVRL1, activin receptorlike kinase 1; HHT, hereditary hemorrhagic telangiectasia; TRV, tricuspid regurgitation velocity; TTCE, transthoracic contrast echocardiography. * Patients were only included if the family mutation was known.

[WU], cardiac index $3.7 \mathrm{~L} / \mathrm{min} / \mathrm{m}^{2}$ ). Patient 4 had no HAVMs and no signs of left heart disease on echocardiography (RHC: PAP 90/26/45 mm Hg, PAWP $19 \mathrm{~mm}$ $\mathrm{Hg}$, PVR 5.6 WU, cardiac index $2.4 \mathrm{~L} / \mathrm{min} / \mathrm{m}^{2}$ ). Pulmonary embolism was excluded with ventilation/perfusion lung scan in both patients. Despite treatment with PAHspecific medication, both patients died due to right heart failure. Patient 5 was classified as high-output $\mathrm{PH}$ based on HAVMs (PAP 63/26/40 mm Hg, PAWP $13 \mathrm{~mm} \mathrm{Hg}$, PVR 2.0 WU, cardiac index $6.4 \mathrm{~L} / \mathrm{min} / \mathrm{m}^{2}$ ). In patient 6 no PH was found (RHC: PAP 30/15/20 mm Hg, PAWP $14 \mathrm{~mm} \mathrm{Hg}$, PVR $0.4 \mathrm{WU}$, cardiac index $8.7 \mathrm{~L} / \mathrm{min} / \mathrm{m}^{2}$ ); however, this patient showed a high CO due to HAVMs.

In the HHT-negative subgroup, none of the controls were classified as high-probability $\mathrm{PH}$.

\section{Discussion}

To our knowledge, this is the first large study reporting the estimated prevalence of $\mathrm{PH}$ in patients with genotyped confirmed HHT compared to HHT-negative controls. Our study demonstrates that the estimated prevalence of $\mathrm{PH}$ is increased in HHT patients compared to
Vorselaars/Velthuis/van Gent/ Westermann/Snijder/Mager/Post 
Table 1. Patient characteristics

\begin{tabular}{|c|c|c|c|c|c|}
\hline & HHT1 & HHT2 & Controls & $\begin{array}{l}p \text { value } \\
\text { (HHT1 vs. } \\
\text { controls) }\end{array}$ & $\begin{array}{l}p \text { value } \\
\text { (HHT2 vs. } \\
\text { controls) }\end{array}$ \\
\hline Patients & 127 & 150 & 106 & & \\
\hline Age, years & $44.2 \pm 15.6$ & $48.9 \pm 14.2$ & $38.6 \pm 12.8$ & 0.002 & $<0.001$ \\
\hline Male sex & $49(38.6 \%)$ & $61(40.7 \%)$ & $40(37.7 \%)$ & 0.9 & 0.7 \\
\hline Clinical diagnosis $^{1}$ & & & & $<0.001$ & $<0.001$ \\
\hline Definite & $117(92.9 \%)$ & $123(82.0 \%)$ & $0(0 \%)$ & & \\
\hline Possible & $9(7.1 \%)$ & $25(16.7 \%)$ & $34(32.1 \%)$ & & \\
\hline Unlikely & $0(0 \%)$ & $2(1.3 \%)$ & $72(67.9 \%)$ & & \\
\hline \multicolumn{6}{|l|}{ Blood pressure, $\mathrm{mm} \mathrm{Hg}$} \\
\hline Systolic & $131.0 \pm 16.0$ & $133.8 \pm 16.0$ & $128.6 \pm 14.9$ & 0.2 & 0.01 \\
\hline Diastolic & $77.2 \pm 7.8$ & $77.7 \pm 8.2$ & $76.7 \pm 7.1$ & 0.6 & 0.3 \\
\hline \multicolumn{6}{|l|}{ Other } \\
\hline Saturation, \% & $97.1 \pm 2.2$ & $97.5 \pm 1.3$ & $97.8 \pm 1.0$ & 0.003 & 0.08 \\
\hline $\mathrm{PaO}_{2}, \mathrm{kPa}$ & $11.6 \pm 2.0$ & $12.1 \pm 1.5$ & $12.5 \pm 1.5$ & 0.001 & 0.04 \\
\hline $\mathrm{Hb}, \mathrm{mmol} / \mathrm{L}$ & $8.5 \pm 1.4$ & $8.2 \pm 1.4$ & $8.6 \pm 0.8$ & 0.4 & 0.01 \\
\hline \multicolumn{6}{|l|}{ Hepatic involvement } \\
\hline Abnormal GGT/ALP & $4(3.1 \%)$ & $26(17.3 \%)$ & $0(0 \%)$ & 0.07 & $<0.001$ \\
\hline $\mathrm{HAVM}^{2}$ & $4(3.1 \%)$ & $22(14.7 \%)$ & $0(0.0 \%)$ & 0.07 & $<0.001$ \\
\hline \multicolumn{6}{|l|}{ Pulmonary involvement } \\
\hline TTCE: pulmonary RLS & $110(86.6 \%)$ & $58(38.7 \%)$ & $11(10.4 \%)$ & $<0.001$ & $<0.001$ \\
\hline Chest CT: PAVM & $78(61.4 \%)$ & $15(10.0 \%)$ & $0(0.0 \%)$ & $<0.001$ & 0.003 \\
\hline \multicolumn{6}{|l|}{ Echocardiography } \\
\hline Peak TRV, m/s & $2.3 \pm 0.4$ & $2.4 \pm 0.5$ & $2.2 \pm 0.3$ & 0.008 & $<0.001$ \\
\hline RVSP, mm Hg & $27.0 \pm 7.4$ & $28.8 \pm 9.6$ & $24.6 \pm 5.5$ & 0.006 & $<0.001$ \\
\hline $\mathrm{RVDD}, \mathrm{cm}$ & $3.6 \pm 0.5$ & $3.9 \pm 0.6$ & $3.7 \pm 0.4$ & 0.7 & $<0.001$ \\
\hline RA area, $\mathrm{cm}^{2}$ & $14.8 \pm 4.7$ & $17.2 \pm 4.7$ & $14.8 \pm 3.3$ & 0.99 & $<0.001$ \\
\hline LA area, $\mathrm{cm}^{2}$ & $15.5 \pm 4.2$ & $18.3 \pm 4.3$ & $15.6 \pm 3.3$ & 0.9 & $<0.001$ \\
\hline LVEF, \% & $59.6 \pm 8.9$ & $64.1 \pm 6.6$ & $61.8 \pm 8.3$ & 0.08 & 0.04 \\
\hline
\end{tabular}

Values are presented as $n, n(\%)$, or mean \pm standard deviation. ALP, alkaline phosphatase; CT, computed tomography; GGT, gamma-glutamyl transpeptidase; HAVM, hepatic arteriovenous malformation; Hb, hemoglobin; HHT1, hereditary hemorrhagic telangiectasia type 1; HHT2, hereditary hemorrhagic telangiectasia type 2; LA, left atrial; LVEF, left ventricular ejection fraction; $\mathrm{PaO}_{2}$, partial oxygen pressure; PAVM, pulmonary arteriovenous malformation; RA, right atrial; RLS, right-to-left shunt; RVDD, right ventricular diastolic diameter; RVSP, right ventricular systolic pressure; TRV, tricuspid regurgitation velocity; TTCE, transthoracic contrast echocardiography. ${ }^{1}$ Based on the Curaçao criteria [1]. ${ }^{2}$ Abdominal ultrasound/CT only performed if history, physical examination, or blood test results were suggestive for HAVMs.

HHT-negative controls. This increase is most prominent in HHT2 and mainly results from the high CO state associated with HAVMs. However, HPAH is rare in HHT patients.

The prevalence of $\mathrm{PH}$ in HHT has only been described in a few studies. A recently published study [22] with 504 HHT patients showed a $\mathrm{PH}$ prevalence of $5.6 \%$ and an HPAH prevalence of $2.4 \%$. Unfortunately, in that study genetic testing was only available in 8 patients. Two other small studies using echocardiography also reported the estimated prevalence of $\mathrm{PH}$ in HHT patients [20, 21]. Olivieri et al. [20] reported elevated echocardiography-

Pulmonary Hypertension in Patients with HHT based RV systolic pressure in 9 (20\%) out of 44 HHT patients (22 ACVRL1, 3 ENG, 19 unknown mutation). In 7 out of these 9 subjects an ACVRL1 gene mutation was found. Three patients were family members of patients with $\mathrm{HPAH}, 1$ patient had a mitral valve stenosis, and all others had HAVMs. Sopena et al. [21] found a high estimated prevalence (31\%) of $\mathrm{PH}$ in 29 hospitalized patients with HHT with a mean RV systolic pressure of $73 \pm 17.0$ $\mathrm{mm} \mathrm{Hg}$ measured by echocardiography. In $67 \%$ of these patients HAVMs were found.

In contrast, in our current study increased-probability $\mathrm{PH}$ was found in $14 \%$ of the HHT patients $(13.7 \%$ in the

Respiration 2017;94:242-250 245 
Table 2. Characteristics of patients with increased-probability pulmonary hypertension

\begin{tabular}{|c|c|c|c|}
\hline & HHT1 & НHT2 & Controls \\
\hline Patients & $11(8.7 \%)$ & $27(18.0 \%)$ & $4(3.8 \%)$ \\
\hline Age, years & $55.2 \pm 16.3$ & $57.9 \pm 14.2$ & $41.6 \pm 18.0$ \\
\hline Male sex & $4(36.4 \%)$ & $7(25.9 \%)$ & $1(25.0 \%)$ \\
\hline \multicolumn{4}{|l|}{ Blood pressure, $\mathrm{mm} \mathrm{Hg}$} \\
\hline Systolic & $129.4 \pm 15.0$ & $132.9 \pm 16.3$ & $135.0 \pm 21.8$ \\
\hline Diastolic & $74.5 \pm 8.8$ & $75.8 \pm 7.0$ & $83.3 \pm 11.5$ \\
\hline \multicolumn{4}{|l|}{ Other } \\
\hline Saturation, $\%$ & $97.3 \pm 0.9$ & $96.8 \pm 2.2$ & $96.3 \pm 1.2$ \\
\hline $\mathrm{PaO}_{2}, \mathrm{kPa}$ & $11.2 \pm .2 .0$ & $11.5 \pm 1.3$ & $10.0 \pm 1.1$ \\
\hline $\mathrm{Hb}, \mathrm{mmol} / \mathrm{L}$ & $7.6 \pm 1.6$ & $7.4 \pm 1.1$ & $8.2 \pm 1.3$ \\
\hline \multicolumn{4}{|l|}{ Hepatic involvement } \\
\hline Abnormal GGT/ALP & $1(9.1 \%)$ & $13(48.1 \%)$ & $0(0 \%)$ \\
\hline $\mathrm{HAVM}^{1}$ & $1(9.1 \%)$ & $12(44.4 \%)$ & $0(0 \%)$ \\
\hline \multicolumn{4}{|l|}{ Pulmonary involvement } \\
\hline TTCE: pulmonary RLS & $10(90.9 \%)$ & $13(48.1 \%)$ & $1(25.0 \%)$ \\
\hline Chest CT: PAVM & $6(54.4 \%)$ & $3(11.1 \%)$ & $0(0 \%)$ \\
\hline \multicolumn{4}{|l|}{ Echocardiography } \\
\hline $\mathrm{TRV}, \mathrm{m} / \mathrm{s}$ & $3.0 \pm 0.4$ & $3.1 \pm 0.4$ & $2.8 \pm 0.1$ \\
\hline RVSP, mm Hg & $42.2 \pm 9.9$ & $43.9 \pm 10.5$ & $38.3 \pm 2.5$ \\
\hline $\mathrm{RVDD}, \mathrm{cm}$ & $3.6 \pm 0.9$ & $4.2 \pm 0.7$ & $3.8 \pm 0.2$ \\
\hline $\mathrm{RA}$ area, $\mathrm{cm}^{2}$ & $17.5 \pm 10.2$ & $19.6 \pm 6.3$ & $16.3 \pm 1.4$ \\
\hline $\mathrm{LA}$ area, $\mathrm{cm}^{2}$ & $18.3 \pm 8.1$ & $21.0 \pm 5.1$ & $18.3 \pm 3.0$ \\
\hline LVEF, \% & $58.3 \pm 12.4$ & $63.8 \pm 8.6$ & $62.0 \pm 7.4$ \\
\hline $\mathrm{CO}, \mathrm{L} / \mathrm{min}$ & $3.9 \pm 1.0$ & $5.1 \pm 1.6$ & $4.4 \pm 0.9$ \\
\hline
\end{tabular}

Values are presented as $n(\%)$ or mean \pm standard deviation. ALP, alkaline phosphatase; CO, cardiac output; $\mathrm{CT}$, computed tomography; GGT, gamma-glutamyl transpeptidase; HAVM, hepatic arteriovenous malformation; $\mathrm{Hb}$, hemoglobin; HHT1, hereditary hemorrhagic telangiectasia type 1; HHT2, hereditary hemorrhagic telangiectasia type 2; LA, left atrial; LVEF, left ventricular ejection fraction; $\mathrm{PaO}_{2}$, partial oxygen pressure; $\mathrm{PAVM}$, pulmonary arteriovenous malformation; RA, right atrial; RLS, right-to-left shunt; RVDD, right ventricular diastolic diameter; RVSP, right ventricular systolic pressure; TRV, tricuspid regurgitation velocity; TTCE, transthoracic contrast echocardiography. ${ }^{1}$ Abdominal ultrasound/CT only performed if history, physical examination, or blood test results were suggestive for HAVMs.

overall HHT group; $8.7 \%$ in the HHT1 and $18.0 \%$ in the HHT2 group). Therefore, our results are not similar to the last two studies. The lower estimated prevalence compared to the previous studies may be due to inclusion at the time of screening, when most patients are asymptomatic.

In HHT, PH can be categorized into two distinct types.

(1) PH is the result of a high pulmonary blood flow that accompanies the high CO state associated with HAVMs $[11,13,29]$. In patients with HAVMs, shunting of blood from the hepatic arteries and/or portal veins to the hepatic veins results in a hyperdynamic state, in which $\mathrm{CO}$ can be elevated up to threefold [30]. Exercise testing in healthy persons revealed that an increase in $\mathrm{CO}$ leads to elevation in PAP (increase in mean PAP up to 0.5-
3.0 $\mathrm{mm} \mathrm{Hg} / \mathrm{L} / \mathrm{min}$ ) [31]. This implicates that a high $\mathrm{CO}$ state of $10 \mathrm{~L} / \mathrm{min}$ will result in a mean PAP up to $30 \mathrm{~mm}$ $\mathrm{Hg}$ without presence of pulmonary arteriopathy. In HHT, a multifactorial cascade will eventually lead to high-output cardiac failure. First, the increase in $\mathrm{CO}$ will be compensated by dilation of the pulmonary arteries with normal pulmonary pressures. An increase in LA pressure will predispose patients for atrial fibrillation (due to LA enlargement) and diastolic dysfunction of the left ventricle. Increased LA pressure and impaired pulmonary vasodilation will eventually result in $\mathrm{PH}$. The combination of volume and pressure overload leads to RV dilation, decreased RV systolic function, and subsequent right heart failure. Especially in HHT, severe bleeding (e.g., epistaxis or gastrointestinal bleeding) and anemia, which many pa- 
Table 3. Predictors for increased-probability pulmonary hypertension

\begin{tabular}{|c|c|c|c|c|}
\hline & $\mathrm{TRV} \leq 2.8 \mathrm{~m} / \mathrm{s}$ & $\mathrm{TRV}>2.8 \mathrm{~m} / \mathrm{s}$ & $\begin{array}{l}\text { Univariate analysis, } \\
\text { OR }[95 \% \mathrm{CI}]\end{array}$ & $p$ value \\
\hline Patients & $341(89.0 \%)$ & $42(11.0 \%)$ & & \\
\hline Age, years & $43.3 \pm 14.3$ & $55.6 \pm 15.4$ & $1.1[1.0-1.1]$ & $<0.001$ \\
\hline Male sex & $138(40.5 \%)$ & $12(28.6 \%)$ & $1.7[0.8-3.4]$ & 0.1 \\
\hline Mutation & & & & 0.002 \\
\hline$E N G$ & $116(34.0 \%)$ & $11(26.2 \%)$ & $2.4[0.7-7.8]$ & 0.1 \\
\hline$A C V R L 1$ & $123(36.1 \%)$ & $27(64.3 \%)$ & $5.6[1.9-16.5]$ & 0.002 \\
\hline Control & $102(29.9 \%)$ & $4(9.5 \%)$ & reference & \\
\hline \multicolumn{5}{|l|}{ Blood pressure, $\mathrm{mm} \mathrm{Hg}$} \\
\hline Systolic & $131.3 \pm 15.8$ & $132.1 \pm 15.9$ & $1.0[1.0-1.0]$ & 0.8 \\
\hline Diastolic & $77.4 \pm 7.7$ & $76.0 \pm 8.0$ & $1.0[0.9-1.0]$ & 0.3 \\
\hline \multicolumn{5}{|l|}{ Other } \\
\hline Saturation, \% & $97.5 \pm 1.6$ & $96.9 \pm 1.9$ & $0.8[0.7-1.0]$ & 0.05 \\
\hline $\mathrm{PaO}_{2}, \mathrm{kPa}$ & $12.1 \pm 1.7$ & $11.3 \pm 1.5$ & $0.8[0.6-0.9]$ & 0.01 \\
\hline $\mathrm{Hb}, \mathrm{mmol} / \mathrm{L}$ & $8.5 \pm 1.2$ & $7.6 \pm 1.2$ & $0.6[0.5-0.7]$ & $<0.001$ \\
\hline \multicolumn{5}{|l|}{ Hepatic involvement } \\
\hline Abnormal GGT/ALP & $16(4.8 \%)$ & $14(33.3 \%)$ & $9.9[4.4-22.4]$ & $<0.001$ \\
\hline $\mathrm{HAVM}^{1}$ & $13(3.8 \%)$ & $13(31.0 \%)$ & $11.3[4.8-26.7]$ & $<0.001$ \\
\hline \multicolumn{5}{|l|}{ Pulmonary involvement } \\
\hline TTCE: pulmonary RLS & $155(45.5 \%)$ & $24(57.1 \%)$ & $1.6[0.8-3.0]$ & 0.2 \\
\hline Chest CT: PAVM & $84(24.6 \%)$ & $9(21.4 \%)$ & $0.8[0.4-1.8]$ & 0.6 \\
\hline \multicolumn{5}{|l|}{ Echocardiography } \\
\hline LA area, $\mathrm{cm}^{2}$ & $16.2 \pm 3.8$ & $20.0 \pm 5.9$ & $1.2[1.1-1.3]$ & $<0.001$ \\
\hline LVEF, \% & $61.8 \pm 8.0$ & $62.2 \pm 9.6$ & $1.0[1.0-1.1]$ & 0.8 \\
\hline
\end{tabular}

Values are presented as $n(\%)$ or mean \pm standard deviation unless indicated otherwise. ACVRL1, activin receptor-like kinase 1; ALP, alkaline phosphatase; CI, confidence interval; CT, computed tomography; GGT, gamma-glutamyl transpeptidase; HAVM, hepatic arteriovenous malformation; Hb, hemoglobin; LA, left atrial; LVEF, left ventricular ejection fraction; OR, odds ratio; $\mathrm{PaO}_{2}$, partial oxygen pressure; PAVM, pulmonary arteriovenous malformation; RLS, right-to-left shunt; TRV, tricuspid regurgitation velocity; TTCE, transthoracic contrast echocardiography. ${ }^{1}$ Abdominal ultrasound/CT only performed if history, physical examination, or blood test results were suggestive for HAVMs.

tients experience, may trigger this cascade due to an increase in CO $[11,29,30]$. This hypothesis was confirmed in our study, as hemoglobin was a predictor for increasedprobability $\mathrm{PH}$ (OR 0.6, 95\% CI 0.5-0.7). HAVMs are typically seen in HHT2; however, HAVMs in patients with HHT1 have also been reported [23, 32]. Our study supports this pattern, as HAVMs were found in $3.1 \%$ of HHT1 and $15.3 \%$ of HHT2 patients. Interestingly, HAVMs were diagnosed in $44.4 \%$ in the HHT2 subgroup with increased-probability $\mathrm{PH}$, which resulted in an increased CO. Moreover, HAVMs were an important predictor for increased-probability PH (OR 11.3, 95\% CI $4.8-26.7)$.

(2) In HHT, precapillary HPAH due to the HHT-related gene mutations in $E N G$ or especially $A C V R L 1$ might develop [14-19]. Another TGF $\beta$ receptor, bone morpho-

Pulmonary Hypertension in Patients with HHT genetic protein receptor type II (BMPRII), was already known for its association with HPAH [33]. In 2001, it was demonstrated that different mutations in ACVRL1 predispose patients for the development of HPAH [14]. This association was confirmed in a few case series describing the presence of HPAH in patients with an ACVRL1 mutation and clinical features of HHT $[8,14,15,17-19]$. Trembath et al. [14] described that mutations in ACVRL1 may lead to occlusion of the pulmonary arteries, resulting in HPAH, together with vascular dilation, manifesting as AVMs in HHT. Importantly, HPAH patients with an ACVRL1 mutation are diagnosed at a younger age and have a worse prognosis than other patients with HPAH [8]. ENG mutations have also been identified in patients with both HHT and HPAH, although this has been described less frequently $[16,17,34]$.

Respiration 2017;94:242-250 247 
Although HPAH is rare in HHT, in this study $0.7 \%$ of HHT patients (1.3\% of the HHT2 group) screened with Doppler echocardiography were found to have $\mathrm{PH}$ clinically attributable to HPAH. Therefore, the estimated prevalence of HPAH in HHT patients seems to be increased compared to the general population (HPAH prevalence $5.9-50$ per one million persons) $[9,35,36]$. We found no HPAH in the HHT1 group. However, for this very rare condition, even our large study might be too small.

Other etiologies of $\mathrm{PH}[9,28,37]$ might also be present in HHT patients (e.g., $\mathrm{PH}$ due to diastolic dysfunction of the left ventricle or chronic thromboembolic $\mathrm{PH}$ [CTEPH]). Since we used a control group, it is less likely that these factors contributed to the difference in TRV between the groups. However, given the substantial age and LA area difference between patients with and without increased probability, diastolic dysfunction of the LV could have contributed to the increase in TRV found in HHT. Alternatively, high CO could also lead to increased LA pressure, resulting in LA enlargement, which makes patients more prone for diastolic dysfunction. The prevalence of left heart failure increases with age, with a low prevalence in patients under 65 years of age (prevalence $0.9 \%$ in the general population aged 55-64 years) [38]. The mean age of HHT patients with increased-probability $\mathrm{PH}$ was approximately 55 years in our study, therefore it seems less likely that isolated diastolic dysfunction of the left ventricle could have had a significant influence on the prevalence of $\mathrm{PH}[39,40]$. We did not rule out CTEPH in all patients with an increased TRV, and there is some evidence that HHT patients have a higher coagulability [41]. However, CTEPH was excluded in patients diagnosed with HPAH and there is no literature describing an increased prevalence of CTEPH in HHT.

Because of the potentially fatal prognosis, the nonspecific symptoms, and the increased estimated prevalence of $\mathrm{PH}$ in HHT, we recommend to refer all HHT patients to an HHT center of excellence.

\section{Study Limitations}

This study has some limitations. (1) We could only measure a reliable TRV in $66 \%$, thus it is possible that we missed some subjects with a high TRV. However, other parameters, such as the RV and RA dimensions (mean $\mathrm{RV}$ dimension $3.7 \pm 0.5 \mathrm{~cm}$ and RA area $15.4 \pm 4.1 \mathrm{~cm}^{2}$ ), that could suggest $\mathrm{PH}$, were normal in all excluded subjects [42]. Therefore, this subgroup could be classified as low-probability PH [9]. (2) Invasive hemodynamic measurements were only performed in a few patients, as sup- ported by the guidelines [9]. Therefore, it is possible that the estimated amount of $\mathrm{PH}$ is overrated and does not reflect the true proportion of patients. (3) It is possible that we missed some patients with HAVMs because imaging (Doppler ultrasound) was not performed in all patients. Importantly, most HAVMs are small and do not lead to symptoms or abnormal biomarkers [32]. High morbidity and mortality are only associated with symptomatic HAVMs. Hence, the international guidelines recommend screening for HAVMs with Doppler ultrasound only when medical history, physical examination, or blood test results are suggestive [2]. However, this could have led to bias toward the presence of HAVMs in HHT2 and $\mathrm{PH}$ patients. (4) Since no mutation in ENG or $A C V R L 1$ is found in approximately $2 \%$ of HHT patients, this study does not apply to this small subgroup [23]. (5) No multivariate analysis was performed. Future studies including more patients might provide more insight into this subject by providing adjusted associations.

\section{Conclusion}

The estimated prevalence of $\mathrm{PH}$ is increased in HHT patients compared to HHT-negative controls. The estimated prevalence of $\mathrm{PH}$ is particularly high in HHT2 patients and results from the high CO state due to the presence of HAVMs. HPAH appears to be rare in HHT patients $(0.7 \%)$ and was only diagnosed in HHT2 (1.3\%).

\section{Financial Disclosure and Conflicts of Interest}

The authors have no conflicts of interest. This work received no financial support.

\section{Author Contributions}

Conception and design: V.M.M.V., S.V., M.W.F.G., C.J.J.W., R.J.S., J.J.M., M.C.P. Analysis: V.M.M.V., S.V., R.J.S., J.J.M., M.C.P. Interpretation: V.M.M.V., S.V., M.W.F.G., C.J.J.W., R.J.S., J.J.M., M.C.P. Drafting: V.M.M.V., S.V., R.J.S., J.J.M., M.C.P. Revision: V.M.M.V., S.V., M.W.F.G., C.J.J.W., R.J.S., J.J.M., M.C.P. Final approval: V.M.M.V., S.V., M.W.F.G., C.J.J.W., R.J.S., J.J.M., M.C.P. Agreement to be accountable for all aspects of the work: V.M.M.V., S.V., M.W.F.G., C.J.J.W., R.J.S., J.J.M., M.C.P. Both V.M.M.V. and M.C.P. are guarantors of the manuscript.
Vorselaars/Velthuis/van Gent/ Westermann/Snijder/Mager/Post 


\section{References}

1 Shovlin CL, Guttmacher AE, Buscarini E, Faughnan ME, Hyland RH, Westermann CJ, Kjeldsen AD, Plauchu H: Diagnostic criteria for hereditary hemorrhagic telangiectasia (Rendu-Osler-Weber syndrome). Am J Med Genet 2000;91:66-67.

2 Faughnan ME, Palda VA, Garcia-Tsao G, Geisthoff UW, McDonald J, Proctor DD, Spears J, Brown DH, Buscarini E, Chesnutt MS, Cottin V, Ganguly A, Gossage JR, Guttmacher AE, Hyland RH, Kennedy SJ, Korzenik J, Mager JJ, Ozanne AP, Piccirillo JF, Picus D, Plauchu H, Porteous ME, Pyeritz RE, Ross DA, Sabba C, Swanson K, Terry P, Wallace MC, Westermann CJ, White RI, Young LH, Zarrabeitia R; HHT Foundation International - Guidelines Working Group: International guidelines for the diagnosis and management of hereditary haemorrhagic telangiectasia. J Med Genet 2011;48:73-87.

3 Velthuis S, Vorselaars VM, Westermann CJ, Snijder RJ, Mager JJ, Post MC: Pulmonary shunt fraction measurement compared to contrast echocardiography in hereditary haemorrhagic telangiectasia patients: time to abandon the $100 \%$ oxygen method? Respiration 2015;89:112-118.

4 Velthuis S, Vorselaars VM, van Gent MW, Westermann CJ, Snijder RJ, Mager JJ, Post MC: Role of transthoracic contrast echocardiography in the clinical diagnosis of hereditary hemorrhagic telangiectasia. Chest 2013; 144:1876-1882.

5 Berg J, Porteous M, Reinhardt D, Gallione C, Holloway S, Umasunthar T, Lux A, McKinnon W, Marchuk D, Guttmacher A: Hereditary haemorrhagic telangiectasia: a questionnaire based study to delineate the different phenotypes caused by endoglin and ALK1 mutations. J Med Genet 2003; 40:585590.

6 McAllister KA, Grogg KM, Johnson DW, Gallione CJ, Baldwin MA, Jackson CE, Helmbold EA, Markel DS, McKinnon WC, Murrell $\mathrm{J}$ : Endoglin, a TGF-beta binding protein of endothelial cells, is the gene for hereditary haemorrhagic telangiectasia type 1 . Nat Genet 1994;8:345-351.

7 Berg JN, Gallione CJ, Stenzel TT, Johnson DW, Allen WP, Schwartz CE, Jackson CE, Porteous ME, Marchuk DA: The activin receptor-like kinase 1 gene: genomic structure and mutations in hereditary hemorrhagic telangiectasia type 2. Am J Hum Genet 1997;61: 60-67.

8 Girerd B, Montani D, Coulet F, Sztrymf B, Yaici A, Jais X, Tregouet D, Reis A, DrouinGarraud V, Fraisse A, Sitbon O, O'Callaghan DS, Simonneau G, Soubrier F, Humbert M: Clinical outcomes of pulmonary arterial hypertension in patients carrying an ACVRL1 (ALK1) mutation. Am J Respir Crit Care Med 2010;181:851-861.

9 Galie N, Humbert M, Vachiery JL, Gibbs S, Lang I, Torbicki A, Simonneau G, Peacock
A, Vonk Noordegraaf A, Beghetti M, Ghofrani A, Gomez Sanchez MA, Hansmann G, Klepetko W, Lancellotti P, Matucci M, McDonagh T, Pierard LA, Trindade PT, Zompatori M, Hoeper M, Aboyans V, Vaz Carneiro A, Achenbach S, Agewall S, Allanore Y, Asteggiano R, Paolo Badano L, Albert Barbera J, Bouvaist H, Bueno H, Byrne RA, Carerj S, Castro G, Erol C, Falk V, Funck-Brentano C, Gorenflo M, Granton J, Iung B, Kiely DG, Kirchhof P, Kjellstrom B, Landmesser U, Lekakis J, Lionis C, Lip GY, Orfanos SE, Park MH, Piepoli MF, Ponikowski P, Revel MP, Rigau D, Rosenkranz S, Voller H, Luis Zamorano J: 2015 ESC/ERS Guidelines for the diagnosis and treatment of pulmonary hypertension: The Joint Task Force for the Diagnosis and Treatment of Pulmonary Hypertension of the European Society of Cardiology (ESC) and the European Respiratory Society (ERS): Endorsed by: Association for European Paediatric and Congenital Cardiology (AEPC), International Society for Heart and Lung Transplantation (ISHLT). Eur Heart J 2016; 37:67-119.

10 Huang J, Mehta S, Mura M: Early decline in six-minute walk distance from the time of diagnosis predicts clinical worsening in pulmonary arterial hypertension. Respiration 2015; 89:365-373.

11 Faughnan ME, Granton JT, Young LH: The pulmonary vascular complications of hereditary haemorrhagic telangiectasia. Eur Respir J 2009;33:1186-1194.

12 Circo S, Gossage JR: Pulmonary vascular complications of hereditary haemorrhagic telangiectasia. Curr Opin Pulm Med 2014;20: 421-428.

13 Cottin V, Dupuis-Girod S, Lesca G, Cordier JF: Pulmonary vascular manifestations of hereditary hemorrhagic telangiectasia (RenduOsler disease). Respiration 2007;74:361-378.

14 Trembath RC, Thomson JR, Machado RD, Morgan NV, Atkinson C, Winship I, Simonneau G, Galie N, Loyd JE, Humbert M, Nichols WC, Morrell NW, Berg J, Manes A, McGaughran J, Pauciulo M, Wheeler L: Clinical and molecular genetic features of pulmonary hypertension in patients with hereditary hemorrhagic telangiectasia. N Engl J Med 2001;345:325-334.

15 Harrison RE, Berger R, Haworth SG, Tulloh R, Mache CJ, Morrell NW, Aldred MA, Trembath RC: Transforming growth factor-beta receptor mutations and pulmonary arterial hypertension in childhood. Circulation 2005; 111:435-441.

16 Mache CJ, Gamillscheg A, Popper HH, Haworth SG: Early-life pulmonary arterial hypertension with subsequent development of diffuse pulmonary arteriovenous malformations in hereditary haemorrhagic telangiectasia type 1 . Thorax 2008;63:85-86.

17 Mahmoud M, Borthwick GM, Hislop AA, Arthur HM: Endoglin and activin receptor-like- kinase 1 are co-expressed in the distal vessels of the lung: implications for two familial vascular dysplasias, HHT and PAH. Lab Invest 2009;89:15-25.

18 Smoot LB, Obler D, McElhinney DB, Boardman K, Wu BL, Lip V, Mullen MP: Clinical features of pulmonary arterial hypertension in young people with an ALK1 mutation and hereditary haemorrhagic telangiectasia. Arch Dis Child 2009;94:506-511.

19 Abdalla SA, Gallione CJ, Barst RJ, Horn EM, Knowles JA, Marchuk DA, Letarte M, Morse JH: Primary pulmonary hypertension in families with hereditary haemorrhagic telangiectasia. Eur Respir J 2004;23:373-377.

20 Olivieri C, Lanzarini L, Pagella F, Semino L, Corno S, Valacca C, Plauchu H, Lesca G, Barthelet M, Buscarini E, Danesino C: Echocardiographic screening discloses increased values of pulmonary artery systolic pressure in 9 of 68 unselected patients affected with hereditary hemorrhagic telangiectasia. Genet Med 2006;8:183-190.

21 Sopena B, Perez-Rodriguez MT, Portela D, Rivera A, Freire M, Martinez-Vazquez C: High prevalence of pulmonary hypertension in patients with hereditary hemorrhagic telangiectasia. Eur J Intern Med 2013;24:e30e34.

22 Lyle MA, Fenstad ER, McGoon MD, Frantz RP, Krowka MJ, Kane GC, Swanson KL: Pulmonary hypertension in the setting of hereditary hemorrhagic telangiectasia. Chest 2015; 149:362-371.

23 Letteboer TG, Zewald RA, Kamping EJ, de Haas G, Mager JJ, Snijder RJ, Lindhout D, Hennekam FA, Westermann CJ, Ploos van Amstel JK: Hereditary hemorrhagic telangiectasia: ENG and ALK-1 mutations in Dutch patients. Hum Genet 2005;116:8-16.

24 Kalogeropoulos AP, Siwamogsatham S, Hayek S, Li S, Deka A, Marti CN, Georgiopoulou VV, Butler J: Echocardiographic assessment of pulmonary artery systolic pressure and outcomes in ambulatory heart failure patients. J Am Heart Assoc 2014;3: e000363.

25 Finkelhor RS, Scrocco JD, Madmani M, Rovner A, Pillai D: Discordant Doppler right heart catheterization pulmonary artery systolic pressures: importance of pulmonary capillary wedge pressure. Echocardiography 2014;31:279-284

26 van Gent MW, Post MC, Snijder RJ, Westermann CJ, Plokker HW, Mager JJ: Real prevalence of pulmonary right-to-left shunt according to genotype in patients with hereditary hemorrhagic telangiectasia: a transthoracic contrast echocardiography study. Chest 2010;138:833-839.

27 Velthuis S, Buscarini E, Gossage JR, Snijder RJ, Mager JJ, Post MC: Clinical implications of pulmonary shunting on saline contrast echocardiography. J Am Soc Echocardiogr 2015;28:255-263. 
28 Simonneau G, Gatzoulis MA, Adatia I, Celermajer D, Denton C, Ghofrani A, Gomez Sanchez MA, Krishna Kumar R, Landzberg M, Machado RF, Olschewski H, Robbins IM, Souza R: Updated clinical classification of pulmonary hypertension. J Am Coll Cardiol 2013;62:D34-D41.

29 Vorselaars VM, Velthuis S, Snijder RJ, Vos JA, Mager JJ, Post MC: Pulmonary hypertension in hereditary haemorrhagic telangiectasia. World J Cardiol 2015;7:230-237.

30 Garcia-Tsao G, Korzenik JR, Young L, Henderson KJ, Jain D, Byrd B, Pollak JS, White RI Jr: Liver disease in patients with hereditary hemorrhagic telangiectasia. $\mathrm{N}$ Engl J Med 2000;343:931-936.

31 Naeije R, Vanderpool R, Dhakal BP, Saggar R, Saggar R, Vachiery JL, Lewis GD: Exerciseinduced pulmonary hypertension: physiological basis and methodological concerns. Am J Respir Crit Care Med 2013;187:576583.

32 Buscarini E, Plauchu H, Garcia Tsao G, White RI Jr, Sabba C, Miller F, Saurin JC, Pelage JP, Lesca G, Marion MJ, Perna A, Faughnan ME: Liver involvement in hereditary hemorrhagic telangiectasia: consensus recommendations. Liver Int 2006;26:1040-1046.

33 Sztrymf B, Yaici A, Girerd B, Humbert M: Genes and pulmonary arterial hypertension. Respiration 2007;74:123-132.
34 Harrison RE, Flanagan JA, Sankelo M, Abdalla SA, Rowell J, Machado RD, Elliott CG, Robbins IM, Olschewski H, McLaughlin V, Gruenig E, Kermeen F, Halme M, RaisanenSokolowski A, Laitinen T, Morrell NW, Trembath RC: Molecular and functional analysis identifies ALK-1 as the predominant cause of pulmonary hypertension related to hereditary haemorrhagic telangiectasia. J Med Genet 2003;40:865-871.

35 Peacock AJ, Murphy NF, McMurray JJ, Caballero L, Stewart S: An epidemiological study of pulmonary arterial hypertension. Eur Respir J 2007;30:104-109.

36 Humbert M, Sitbon O, Chaouat A, Bertocchi M, Habib G, Gressin V, Yaici A, Weitzenblum E, Cordier JF, Chabot F, Dromer C, Pison C, Reynaud-Gaubert M, Haloun A, Laurent M, Hachulla E, Simonneau G: Pulmonary arterial hypertension in France: results from a national registry. Am J Respir Crit Care Med 2006;173:1023-1030.

37 Mueller-Mottet S, Stricker H, Domenighetti G, Azzola A, Geiser T, Schwerzmann M, Weilenmann D, Schoch O, Fellrath JM, Rochat T, Lador F, Beghetti M, Nicod L, Aubert JD, Popov V, Speich R, Keusch S, Hasler E, Huber LC, Grendelmeier P, Tamm M, Ulrich S: Long-term data from the Swiss pulmonary hypertension registry. Respiration 2015;89: 127-140.
38 Bleumink GS, Knetsch AM, Sturkenboom MC, Straus SM, Hofman A, Deckers JW, Witteman JC, Stricker BH: Quantifying the heart failure epidemic: prevalence, incidence rate, lifetime risk and prognosis of heart failure. The Rotterdam Study. Eur Heart J 2004;25: 1614-1619.

39 Lee DS, Gona P, Vasan RS, Larson MG, Benjamin EJ, Wang TJ, Tu JV, Levy D: Relation of disease pathogenesis and risk factors to heart failure with preserved or reduced ejection fraction: insights from the Framingham Heart Study of the National Heart, Lung, and Blood Institute. Circulation 2009;119:30703077.

40 Owan TE, Hodge DO, Herges RM, Jacobsen SJ, Roger VL, Redfield MM: Trends in prevalence and outcome of heart failure with preserved ejection fraction. N Engl J Med 2006; 355:251-259.

41 Shovlin CL, Sulaiman NL, Govani FS, Jackson JE, Begbie ME: Elevated factor VIII in hereditary haemorrhagic telangiectasia (HHT): association with venous thromboembolism. Thromb Haemost 2007;98:1031-1039.

42 Rudski LG, Lai WW, Afilalo J, Hua L, Handschumacher MD, Chandrasekaran K, Solomon SD, Louie EK, Schiller NB: Guidelines for the echocardiographic assessment of the right heart in adults: a report from the American Society of Echocardiography endorsed by the European Association of Echocardiography, a registered branch of the European Society of Cardiology, and the Canadian Society of Echocardiography. J Am Soc Echocardiogr 2010;23:685-713. 